\title{
Comparative Efficacy of Antidermatophyte Creams Formulated from Ethanol Extracts of Cassia Occidentalis and Cassia Alata Leaves
}

\author{
F. O. Oyedeji ${ }^{1}$, A. B. Fawehinmi ${ }^{2^{*}}$, S. O. Etatuvie ${ }^{2}$ and Hassan Lawal ${ }^{2}$ \\ ${ }^{1}$ Department of Chemistry, University of Ibadan, Nigeria. \\ ${ }^{2}$ Nigeria Natural Medicine Development Agency, Lagos, Nigeria.
}

\begin{abstract}
Authors' contributions
This work was carried out in collaboration among all authors. Author FOO designed the study, performed the statistical analysis, wrote the protocol and wrote the first draft of the manuscript. Authors ABF and HL managed the analyses of the study. Author SOE managed the literature searches. All authors read and approved the final manuscript.
\end{abstract}

Article Information

DOI: $10.9734 / A R R B / 2021 / v 36 i 430359$

Editor(s):

(1) Dr. Saleha Sadeeqa, Lahore College for Women University, Pakistan.

Reviewers:

(1) Catalina Rivas Morales, Autonomous University of Nuevo León, Mexico. (2) Zhongming Li, Johns Hopkins University, USA. Complete Peer review History: http://www.sdiarticle4.com/review-history/66149

Original Research Article

Received 06 January 2021

Accepted 12 March 2021

Published 23 April 2021

\begin{abstract}
Incidence of drug resistance by dermatophytes is a worldwide concern. Researchers search for natural and better drugs to arrest the ugly situation. This study aims to formulate antidermatophyte Creams with ethanol extracts of the leaves of cassia alata and cassia occidentalis against four selected dermatophytes namely Trichophyton mentagrophtes, Microsporum audounii, Epidermophyton floccosum and Malassezia furfur. Wistar rats were used in determining the efficacy of the formulated herbal creams by examining the biopsies of the skin of the infected rats for presence of fungal hyphae, tissue destruction, Inflammation of the skin, absence of sebaceous gland and also absence of hair follicles. Dekeratinization of the skin layer was also measured. From the result obtained, it was observed that the efficacy of the creams is concentration dependent. Cassia alata cream formulation was particularly effective against three of the dermatophytes namelyTrichophyton mentagrophtes $(30.71 \pm 0.51 \mu \mathrm{m})$ Microsporum audounii $(36.17 \pm 0.59 \mu \mathrm{m})$, and Epidermophyton floccosum $(37.49 \pm 0.18 \mu \mathrm{m})$ while Cassia occidentalis cream was effective against Malassezia furfur $(33.22 \pm 0.16 \mu \mathrm{m})$. The results showed that the plants ethanol extracts can be utilized in the management of dermatophytosis when formulated as a cream for topical use.
\end{abstract}


Keywords: Fungal hyphae; antidermatophyte; cream; epidermal thickness; dekeratinization.

\section{INTRODUCTION}

Dermatophytosis is a common fungal infection that is prevalent in sub-sahara Africa and other developing countries of the world [1]. The constant narative is that skin infection in the world particularly Africa is largely due to poor socioeconomic conditions [2]. Also, dermatophytic infection may be encouraged by the indiscriminate use of topical steroids for lightening purposes [3].

C. alata and cassia occidentalis are two medicinal plants commonly used in the management of dermatophytosis in southwestern Nigeria [4]. While C. alata is called Asuwon egba by the Yoruba speaking people, C. occidentalis is called Asuwon oyinbo. So many medicinal usefulness of cassia alata has been the object of discussion among many researchers who have carried out a lot of chemical and pharmacological studies. It is an ornamental shrub or tree growing up to $12 \mathrm{~m}$ high and widely available in the tropics, in the grasslands and around towns and villages throughout West Africa. In the northern part of Nigeria, particularly in Adamawa and Taraba States, the root, stem and leaves are used by practitioners of herbal medicines to treat burns, skin and wound infections, diarrhoeal diseases, gastrointestinal and upper respiratory tract infections.

C. alata has been extensively studied for its anthracene derivatives [5]. In her studies, Ayo [6] reported that fresh leaves juice is used for the management of ring worm, mycosis, scorpion bite, skin diseases, itching, syphilis sores, herpes and eczema. The flowers, leaves and Roots of the plant is reported to possess many biological properties such as antibacterial, antifungal, antiinflammatory, antitumor, expectorant and they also reported that it is useful in urinary tract problems [7]. Previous workers have suggested that the anthranols (and anthrones) present in Cassia spp. could be the active constituents involved in their use as antiseptics in certain skin diseases [8]. Several studies have been done to provide scientific basis for the efficacy of plants in phytomedicine. Alalor et al. [9] reported that the aqueous and methanol extracts of cassia alata has powerful antifungal properties against Candida albicans, Trichophyton mentagroph yte, Aspergillusiger and Penicillium. They conclu ded that the in vitro findings justified the use of the extracts of $C$. alata in traditional medicine practice for the treatment of some external and fungal infections.

Scientists such as Vedpriya et al. [10], worked on extracts of leaves of C. occidentalis to determine their antimicrobial activities against some bacteria and fungi strains by disk diffusion assay. It was observed that methanol and aqueous extracts showed significant antimicrobial activity against the tested microorganisms. The antimicrobial activity and antioxidant properties of $C$. occidentalis on Escherichia coli, Pseudomonas aeruginosa and Staphylococcus aureus was determined by Sathya et al., who concluded that the aqueous plant extract can be used as antimicrobial agent, antioxidant and also used as herbal medicine for curing number of disease in the form of pellets or paste [11].

\section{MATERIALS AND METHODS}

\subsection{Plant Collection and Identification}

C. occidentalis and C. alata leaves were collected at the Botanical Gardens of Nigeria Natural Medicine Development Agency.

\subsection{Preparation of Plant Extracts}

The fresh leaves were air-dried under shade at room temperature for about 14 days. They were pounded into smaller particles and grounded to fine powder using an electric blender (Kenwood). The powdered samples were stored in airtight containers and kept at room temperature until required.

\subsection{Ethanol Extract Preparation}

The pulverized plant samples $(200 \mathrm{~g})$ of both $C$. occidentalis and C. alata were soaked in $500 \mathrm{~mL}$ of ethanol. The samples were kept on the rotator shaker which was allowed to operate for 72 hours for accelerated agitated extraction. The mixtures were then filtered with Whatman filter paper grade 1 concentrating the filterate using water bath at $60^{\circ} \mathrm{C}$ until the solvent was completely removed.

\subsection{Test Organisms}

The test organisms used were clinical isolates of Microsporium aoudininn, Malassezia furfur, 
Trychophyton mentagrophyte and Epidermophyton floccosum which were obtained from Spectralab Medical and Diagnostic Services, Sagamu, Ogun State.

\subsection{Formulation of Creams}

Oil in water cream was produced by adding the oil phase to the aqueous phase slowly after heating to between $70-75^{\circ} \mathrm{C}$ with continuous stirring. Heating was continued at the same temperature for about 10 - 15 minutes. The coarse cream formed were then cooled to about $35^{\circ} \mathrm{C}$ gradually. The cream was allowed to stay at room temperature for twelve hours and then homogenized with the aid of a mechanical stirrer. Three different creams containing 0.5, 1 and $2 \%$ of $C$. occidentalis and $C$. alata ethanolic extracts were produced. The prepared herbal creams were then vigorously homogenized.

\subsection{In Vivo Antidermatophytic Activity}

Laboratory Animals: Wistar rats weighing between 150-200 g were obtained from the Experimental Animal Unit of the Faculty of Veterinary Medicine of the University of Ibadan. They were kept in well ventilated rat cages with free access to water and feed and were left in this environment for two [2] weeks to acclimatize [12]. Selection and grouping of animals: The animals were allocated to seven [7] groups. The rats were then inoculated with the dermatophytes. One week after inoculation of the animals with the dermatophytes, the inoculated skin area of $2 \mathrm{~cm} 2$ were treated with the plants extracts and the formulated creams with plants extracts for seven days. At the end of seven days, the animals were euthanized by cervical dislocation.

\subsection{The Experimental Animal Study Design}

Fifty five (55) animals were required per batch and were grouped into 7 groups of 5 rats.

Group 1 -Animals infected but without any treatment - Negative control

Group 2 - Animals infected but treated with cream containing 1\% Clotrimazole (Positive Control - a).

Group 3 - Animals infected and treated with placebo (Emulsion base only/Positive control - b)
Group $4 a-$ Animals treated with $0.5 \%$ medicinal plant extract alone

Group 4b-Animals treated with emulsion containing $0.5 \%$ medicinal plant extract

Group $5 a$ - Animals treated with $1 \%$ medicinal plant extract alone

Group 5b-Animals treated with emulsion containing $1 \%$ medicinal plant extract

Group 6a- Animals treated with $2 \%$ medicinal plant extract alone

Group 6b- Animals treated with emulsion containing $2 \%$ medicinal plant extract

Group 7a - Un-infected animals (normal skin condition - control)

Group 7b-Uninfected animals with patch rubbed with emulsion base.

\subsection{Histopathological Studies}

$2 \mathrm{~cm}$ skin areas were cut and put in 10\% formalin for histopathological analysis. Skin biopsy samples were examined for presence of fungal hyphae, hair follicles, sebaceous gland, inflammation and tissue destruction using light microscope.

\subsection{Statistical Analysis of Data}

Data generated were subjected to statistical analysis using one way ANOVA followed by tukeys post hoc analysis. It is reported as mean \pm SEM. P $\leq 0.05$ was considered significant. Also keratin layer readings were obtained with the aid of calibrated Toupview $\circledR$ software.

\section{RESULTS AND DISCUSSION}

\subsection{Histopathology of Skin Tissues}

Tissues were examined for the presence of fungal elements; inflammation, Fungal hyphae, loss of hair follicles, absence of sebaceous gland and discontinuity/Tissue destruction.

\subsection{Effect of C. alata and C. occidentalis Formulations on Dermatopytes Microsporium aoudinin}

The skin biopsies of animals infected with the dermatophyte showed marked inflammation of the skin and foci of discontinuity of the epidermis as observed in group 1. Marked presence of fungal hyphae was also seen in the group. There 
were no hair follicles seen, but few sebaceous glands were found which further indicated successful infection (Table 1 and Table 2). Marked tissue destruction was also observed in the group (Fig. 1).

There is absence of inflammation and tissue destruction in group 2. It was observed that no fungal hyphae were seen in the group indicating that the drug was able to prevent the infection by the dermatophyte. There were numerous hair follicles in the dermis and also numerous amounts of sebaceous glands. Group 3 animals treated with emulsion alone had moderate presence of fungal hyphae. There were few hair follicles and sebaceous glands in the dermis. Skin inflammation and tissue destruction of the skin were marked in the group. There were moderate presence of fungal hyphae in group 4a (C. alata and C. occidentalis 0.5 extract alone). Few amount of hair follicles enmeshed within the sparseconnective tissue in the dermis were seen. There are moderate amount of sebaceous glands in the dermis. Inflammation and tissue destruction of the skin were also moderate in the group (Table 1 and Table 2).

Group 4b. Few amount of fungal hyphae were seen in group 5 a ( $1 \%$ plants extracts alone) with moderate amount of hair follicle and sebaceous gland (Fig. 2). The inflammation and tissue destruction of the skin were also moderate (Table 1 and Table 2). Same observation were recorded for $5 b \quad(1 \%$ plants extracts in emulsion). In group 6a, Inflammation and tissue destruction of the skin were mild. No fungal hyphae were seen in group $6 a(2 \%$ plant extract alone) for $C$. alata which indicated that the extract was able to prevent the growth of the dermatophyte hyphae however for $C$. occidentalis there were few presence of fungal hyphae in the group (Table 2). For the two medicinal plants, moderate hair follicles in the dermis and also moderate amount of sebaceous glands were observed. Same observations were made for animals in group $6 \mathrm{~b}(2 \%$ plant extract in emulsion).

Table 1. Mycological efficacy of $C$. alata ethanol formulations against Microsporium aoudini

\begin{tabular}{llllll}
\hline Group & $\begin{array}{l}\text { Fungal } \\
\text { hyphae }\end{array}$ & Hair follicles & $\begin{array}{l}\text { Sebaceous } \\
\text { gland }\end{array}$ & Inflammation & $\begin{array}{l}\text { Continuity/Tissue } \\
\text { destruction }\end{array}$ \\
\hline 1 & +++ & - & + & +++ & +++ \\
2 & - & +++ & +++ & - & - \\
3 & ++ & + & + & +++ & +++ \\
$4 a$ & ++ & + & ++ & ++ & ++ \\
$4 b$ & ++ & + & ++ & ++ & ++ \\
$5 a$ & + & ++ & ++ & ++ & ++ \\
$5 b$ & + & ++ & ++ & ++ & + \\
$6 a$ & - & ++ & ++ & + & + \\
$6 b$ & - & ++ & ++ & + &
\end{tabular}

Table 2. Mycological efficacy of Cassia occidentalis formulations against Microsporium aoudini

\begin{tabular}{llllll}
\hline Group & $\begin{array}{l}\text { Fungal } \\
\text { hyphae }\end{array}$ & Hair follicles & $\begin{array}{l}\text { Sebaceous } \\
\text { gland }\end{array}$ & Inflammation & $\begin{array}{l}\text { Continuity/Tissue } \\
\text { destruction }\end{array}$ \\
\hline 1 & +++ & + & + & +++ & +++ \\
2 & - & +++ & +++ & - & - \\
3 & ++ & + & + & +++ & +++ \\
$4 \mathrm{a}$ & ++ & + & + & ++ & ++ \\
$4 \mathrm{~b}$ & ++ & + & + & ++ & ++ \\
$5 \mathrm{a}$ & ++ & ++ & ++ & ++ \\
$5 \mathrm{~b}$ & ++ & ++ & ++ & + \\
$6 \mathrm{a}$ & + & ++ & ++ & + & + \\
$6 \mathrm{~b}$ & + & ++ & + & + \\
\hline \multicolumn{7}{c}{} \\
\hline
\end{tabular}




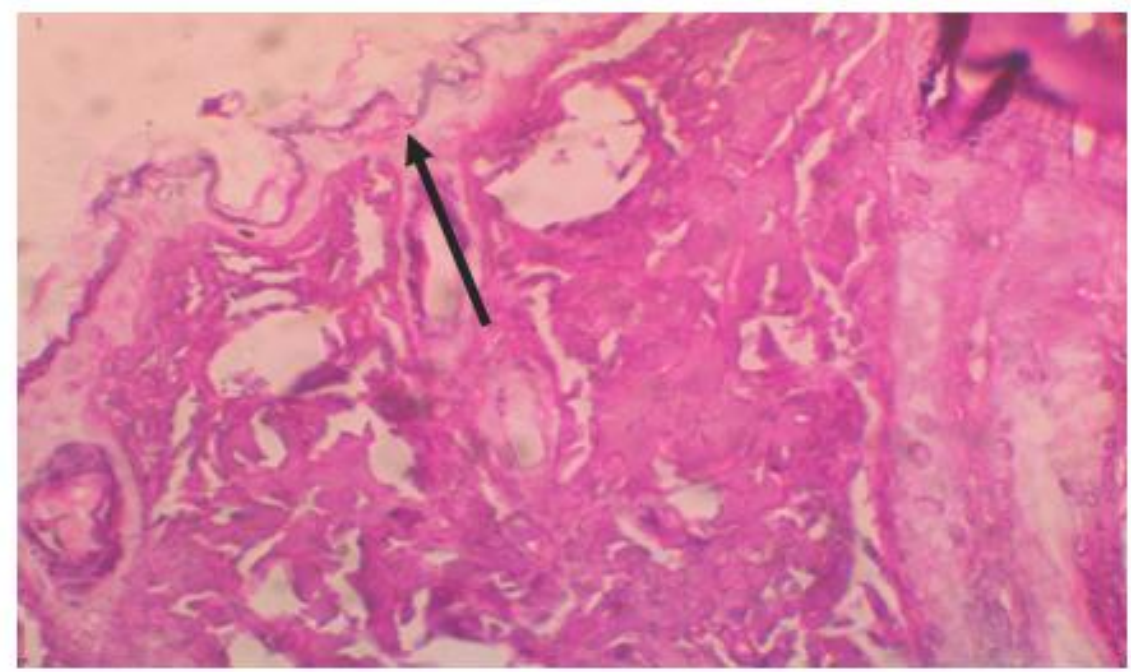

Fig. 1. Thickening of the epidermis due to hyperkeratosis and follicular proliferation (HE x100)

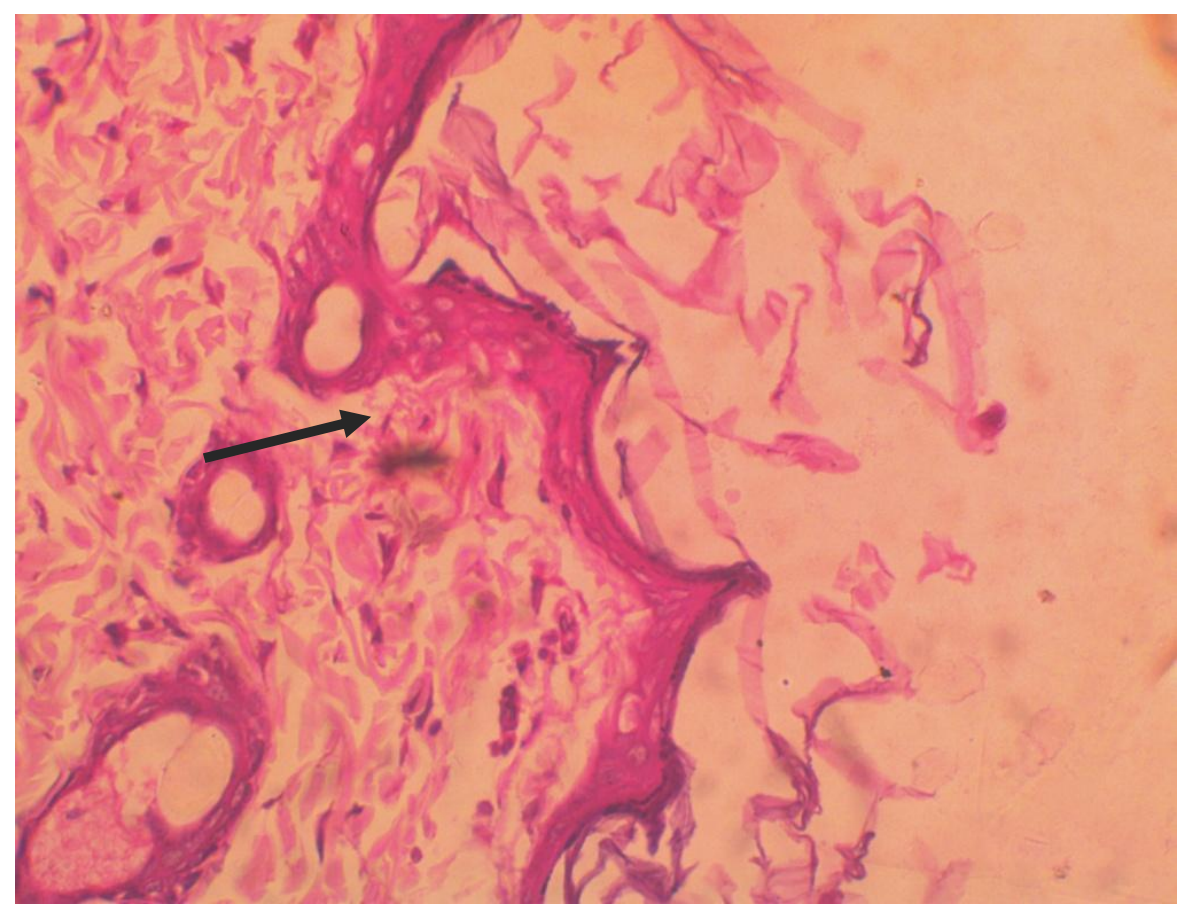

Fig. 2. There is cornification and thicknening of the epidermis HE $\times 100$ This indicated that $2 \% \quad C$. alata and $C$.
occidentalis plants extract alone and $2 \%$ C. alata and $C$. occidentalis plants extracts in emulsion are closely effective as the standard drug. Fig 3 and Fig. 4 showed the efficacy of the formulations on the keratin layer of the hair compared with the infected untreated control. The values obtained for untreated control indicated that the hairs were heavily infected with the dermatophyte. The effectiveness of $1 \%$ clotrimazole cream in preventing attack by the dermatophyte on the keratin layer of the hair is 
demonstrated by the high value recorded. However, the group treated with the emulsion alone showed there was little or no efficacy. Application of $0.5 \%$ C. alata and C. Occidentalis extract emulsion and $0.5 \% \quad C$. alata and $C$. Occidentalis extract alone on the infected skin of the animal did not show any significant difference from the untreated group. This implies that they had no effect in curtailing the infection caused by the dermatophyte.
The efficacy of the formulations increased as the concentration increases which can been seen in the group treated with $1 \% \quad C$. alata and $C$. occidentalis extract alone and $1 \%$ C. alata and $C$. occidentalis emulsion. It was observed that $2 \%$ C. alata alone and $2 \%$ C. alata extract emulsion were more effective than $2 \%$ Cassia occidentalis extract alone and $2 \%$ Cassia occidentalis extract emulsion.

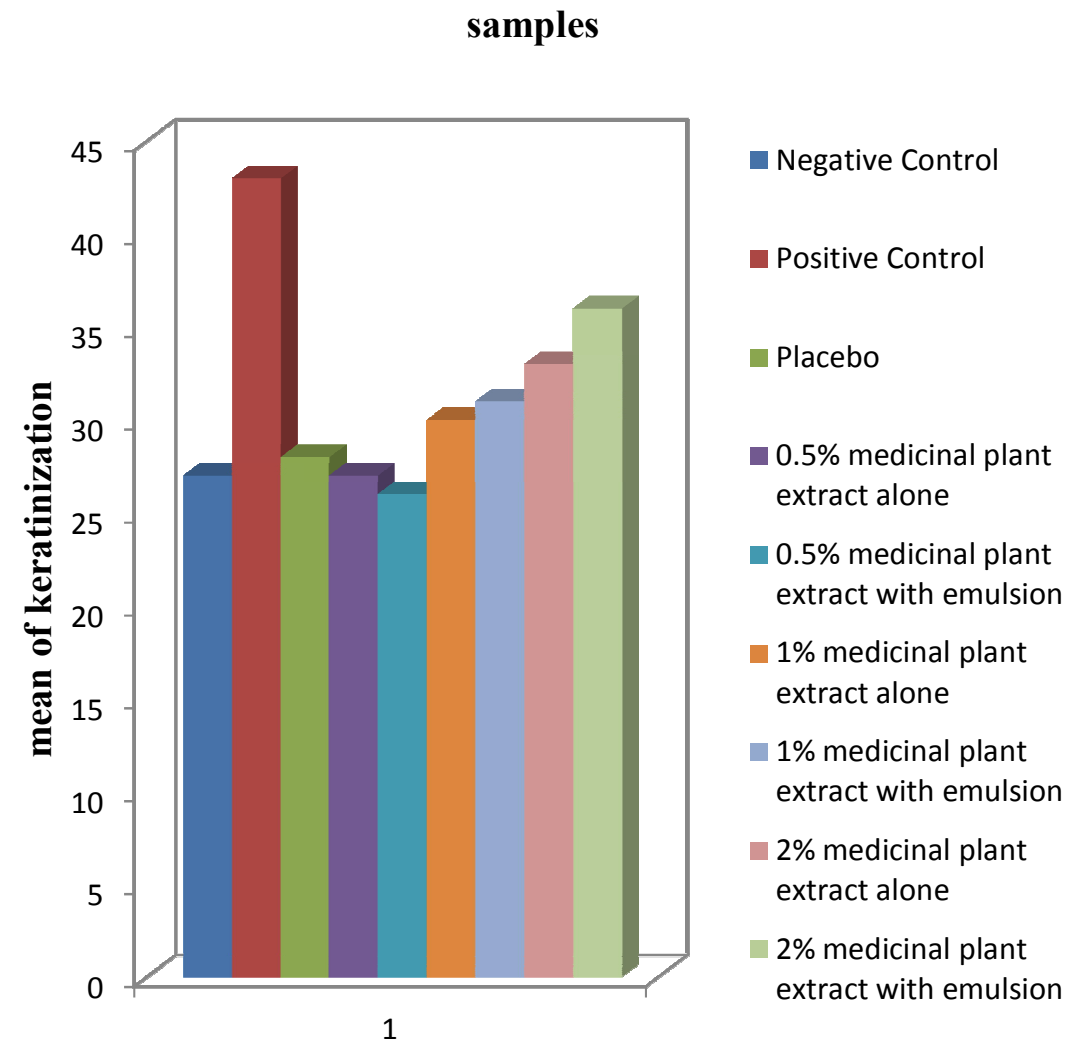

Fig. 3. Effect of Cassia alata extracts on keratinization in Microsporium aoudini infected skin

\subsection{Epidermophyton floccosum}

There was marked inflammation of the skin and tissue destruction observed in group 1 compared to the other groups which were treated with various formulations. Marked presence of fungal hyphae was seen in the group. Few hair follicles and sebaceous glands were also observed. (Table 3 and 4). No inflammation and tissue destruction was observed in group 2. No fungal hyphae were seen indicating that the drug was able to prevent the infection by the dermatophyte. There were numerous hair follicles in the dermis and also numerous amounts of sebaceous glands. Group 3 animals treated with emulsion alone had moderate skin inflammation, and there was marked tissue destruction of the skin. Moderate presence of fungal hyphae and moderate hair follicles were seen. There were few sebaceous glands in the dermis. (Fig. 5). The same observations were made for groups $4 a, 4 b, 5 a$ and $5 \mathrm{~b}$ except for $C$. occidentalis formulations which were able to reduce tissue destruction compared to $C$. alata formulations in $4 a-5 b$ (Fig. 6). 


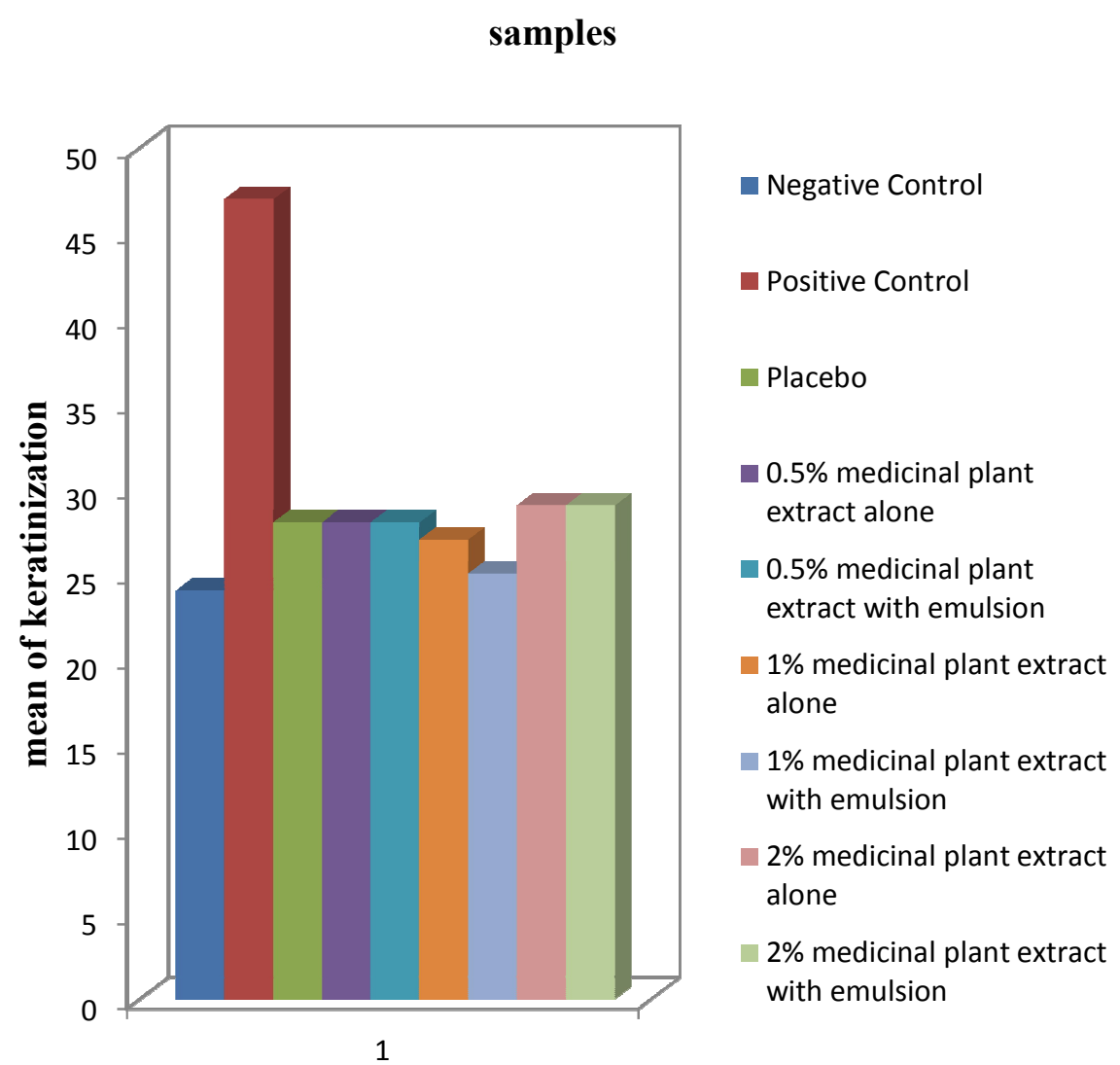

\section{Fig. 4. Effect of Cassia occidentalis extracts on keratinisation in Microsporium aoudinin infected skin}

There was little presence of fungal hyphae in groups $6 a$ and $6 \mathrm{~b}$ for $C$. alata formulations but moderate for $C$. occidentalis formulations. Few amount of hair follicles enmeshed within the sparse connective tissue in the dermis were seen for C. occidentalis formulations (Fig. 6) while it was moderate for C. alata formulations (Fig. 5). There were also moderate amount of sebaceous glands in the dermis for both medicinal plants formulations. Inflammation and tissue destruction of the skin were also moderate for the two medicinal plants. (Fig. 5).

Figs. 7 and 8 shows comparative effectiveness of the formulations on keratinization compared with the infected untreated control. Higher scores indicated improved efficacy. Significant efficacy was demonstrated by $1 \%$ clotrimazole cream. There was significant effect of $0.5 \%$ C. alata formulations compared to that of $C$. Occidentalis formulations (Figs. 6 and 7). Same observation was made for $1.0 \%$ formulations. The efficacy of the formulations increased as the concentration increases which can been seen in the group treated with $2 \% \quad$ C. alata formualtions (Fig.8) which implies that it can be said to be mycologically effective in prevent the dermotophyte in reducing the keratin layer of the hair. The values obtained for $1 \% C$. alata extract alone $(26.52 \pm 0.35 \mu \mathrm{m}), 1 \% \quad$ C. alata extract emulsion $(26.71 \pm 0.24 \mu \mathrm{m}), 0.5 \% \quad C$. alata extract $(25.06 \pm 0.67 \mu \mathrm{m})$ and $0.5 \% \quad$ C. alata extract emulsion $(25.66 \pm 0.74 \mu \mathrm{m})$ showed that the formulations are slightly effective, but not as effective as the $2 \%$ formulations. The value obtained for the emulsion alone $(22.29 \pm 0.44$ $\mu \mathrm{m})$ indicated that it has some antidermatophytic effect compared to the untreated group. 
Table 3. Mycological efficacy of $C$. alata formulations against Epidermophyton floccosum

\begin{tabular}{llllll}
\hline Group & $\begin{array}{l}\text { Fungal } \\
\text { hyphae }\end{array}$ & Hair follicles & $\begin{array}{l}\text { Sebaceous } \\
\text { gland }\end{array}$ & Inflammation & $\begin{array}{l}\text { Continuity/Tissue } \\
\text { destruction }\end{array}$ \\
\hline 1 & +++ & + & + & +++ & +++ \\
2 & - & ++ & +++ & - & - \\
3 & ++ & ++ & + & ++ & +++ \\
$4 \mathrm{a}$ & ++ & ++ & + & ++ & +++ \\
$4 \mathrm{~b}$ & ++ & ++ & + & ++ & +++ \\
$5 \mathrm{a}$ & ++ & ++ & + & ++ & +++ \\
$5 \mathrm{~b}$ & ++ & ++ & + & ++ & +++ \\
$6 \mathrm{a}$ & + & ++ & ++ & ++ & ++ \\
$6 \mathrm{~b}$ & + & ++ & ++ & ++ & ++ \\
\hline \multicolumn{7}{c}{}
\end{tabular}

Table 4. Mycological efficacy of Cassia occidentalis formulations against Epidermophyton floccosum

\begin{tabular}{llllll}
\hline Group & $\begin{array}{l}\text { Fungal } \\
\text { hyphae }\end{array}$ & Hair follicles & $\begin{array}{l}\text { Sebaceous } \\
\text { gland }\end{array}$ & Inflammation & $\begin{array}{l}\text { Continuity/Tissue } \\
\text { destruction }\end{array}$ \\
\hline 1 & +++ & + & + & ++ & +++ \\
2 & - & +++ & ++ & - & - \\
3 & ++ & + & + & ++ & ++ \\
$4 a$ & ++ & + & + & ++ & ++ \\
$4 \mathrm{~b}$ & ++ & + & + & ++ & ++ \\
$5 \mathrm{a}$ & ++ & + & + & ++ & ++ \\
$5 \mathrm{~b}$ & ++ & + & + & ++ & ++ \\
$6 \mathrm{a}$ & ++ & + & ++ & ++ & ++ \\
$6 \mathrm{~b}$ & ++ & + & ++ & ++ & ++ \\
\hline \multicolumn{7}{r}{}
\end{tabular}

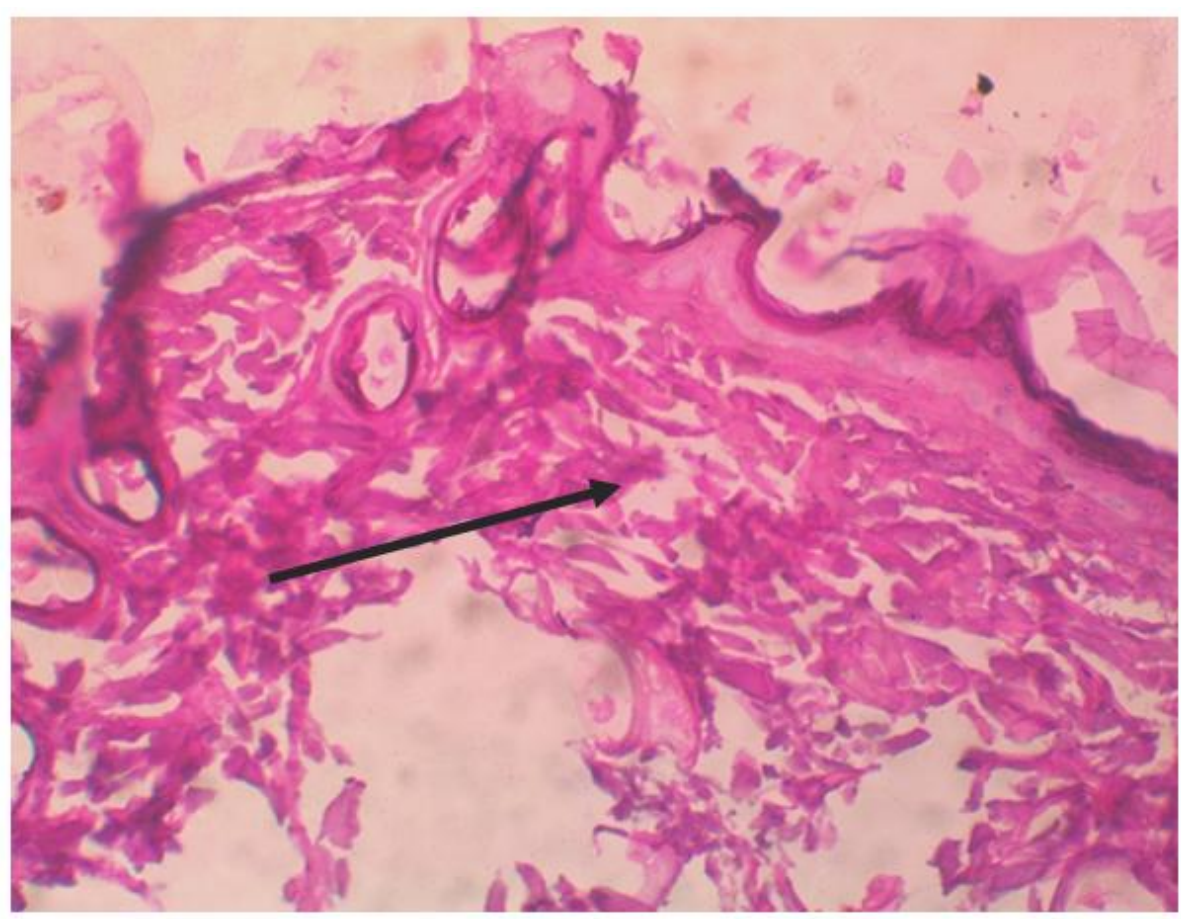

Fig. 5. Discontinuity of skin tissues. HE x100 


\section{samples}

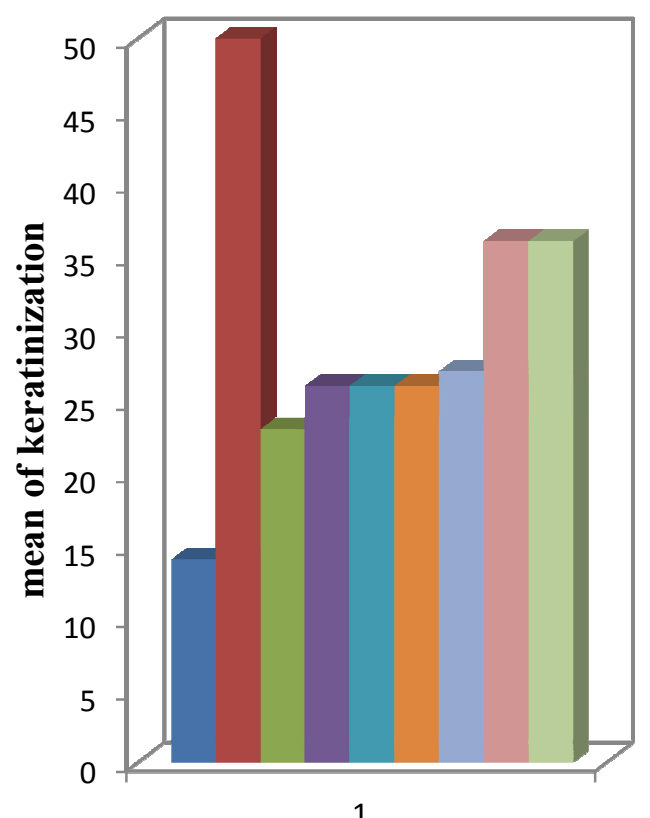

Negative Control

Positive Control

Placebo

$0.5 \%$ medicinal plant extract alone

- $0.5 \%$ medicinal plant extract with emulsion

$1 \%$ medicinal plant extract alone

$1 \%$ medicinal plant extract with emulsion

2\% medicinal plant extract alone

$2 \%$ medicinal plant extract with emulsion

Fig. 6. Effect of Cassia alata extracts on keratinization in Epidermophyton floccosum infected skin

samples

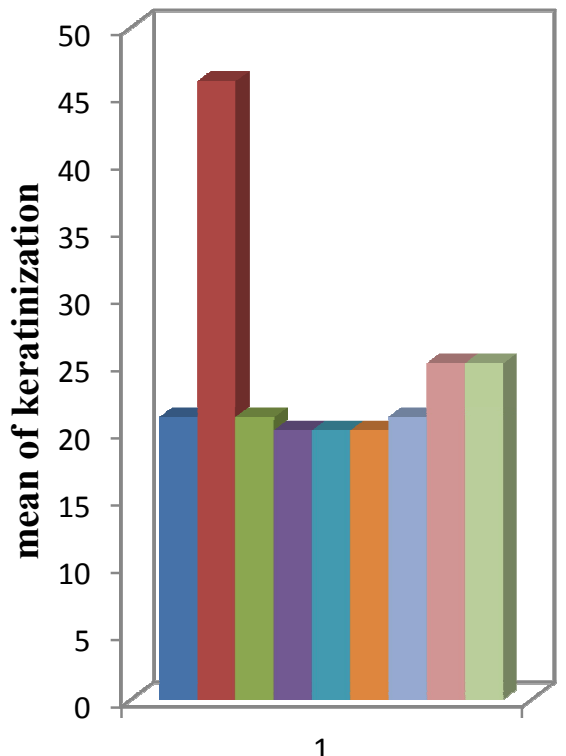

1
Negative Control

Positive Control

Placebo

- $0.5 \%$ medicinal plant extract alone

$0.5 \%$ medicinal plant extract with emulsion

$1 \%$ medicinal plant extract alone

1\% medicinal plant extract with emulsion

$2 \%$ medicinal plant extract alone

Fig. 7. Effect of Cassia occidentalis extracts on keratinization in Epidermophyton floccosum infected skin 


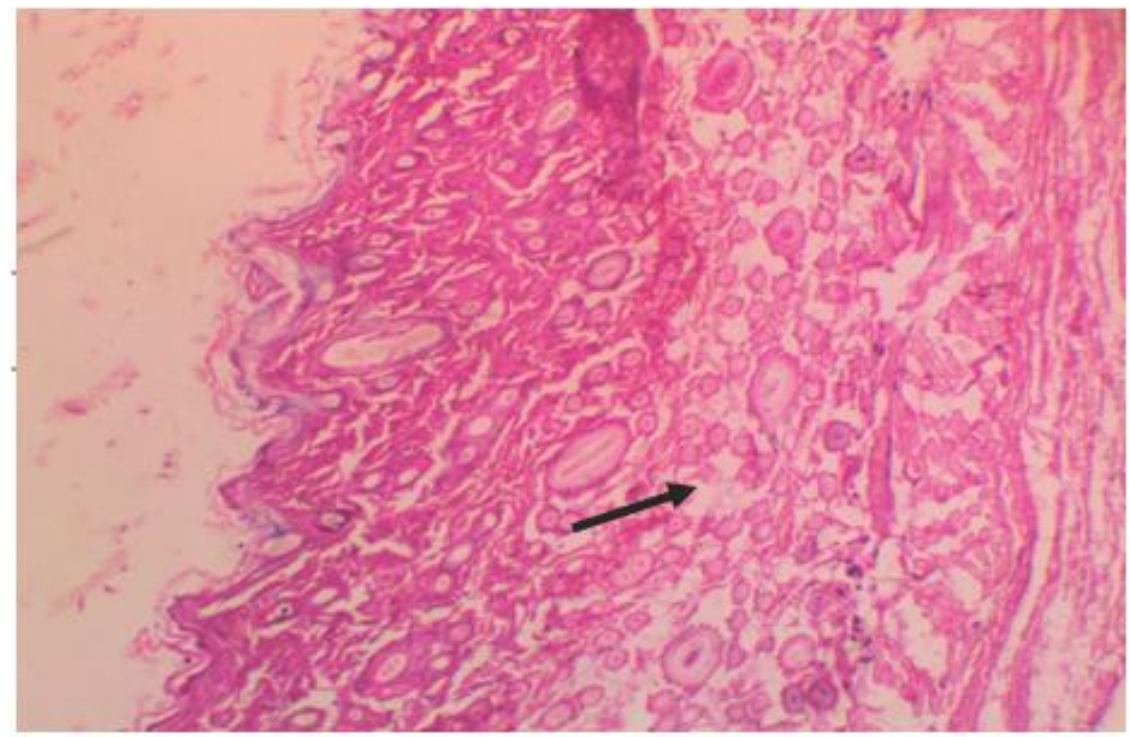

Fig. 8. There is moderate thicknening of the epidermis with few acute Inflammatory. HE x100

\subsection{Trichophyton mentagrophytes}

There was marked inflammation of the skin in group 1. There was also moderate presence of fungal hyphae in the group. Few hair follicles and sebaceous glands were observed. Moderate tissue destruction was also observed in the group (Table 5). No inflammation and tissue destruction was observed in group 2 (Table 5). No fungal hyphae were seen in the group indicating that the drug was able to prevent the infection by the dermatophyte. There were numerous hair follicles in the dermis and also numerous amounts of sebaceous glands. Group 3 animals treated with emulsion alone had moderate skin inflammation and moderate tissue destruction of the skin (Fig.9). Moderate presence of fungal hyphae and few hair follicles seen. There were also few sebaceous glands in the dermis. There was moderate presence of fungal hyphae and few hair follicles in group $4 a$ (C. alata and C. occidentalis 0.5 extract alone) There were also few amounts of sebaceous glands. It was observed that skin inflammation and tissue destruction were moderate (Table 6). The same observations were made for group $4 \mathrm{~b}$ (C. alata and C. occidentalis 0.5 extract emulsion). Results for $5 \mathrm{a}$ and $5 \mathrm{~b}$ (C. alata and $C$. occidentalis $1 \%$ extract alone and $C$. alata and $C$. occidentalis $1 \%$ extract emulsion) are listed in Tables 5 and 6 . While hair follicles and sebaceous glands were few in the groups treated with C. alata $1.0 \%$ extract alone and C. alata
$1.0 \%$ extract emulsion( Table 5), they were moderate in the groups treated with $C$. occidentalis $1.0 \%$ extract alone and C. occidentalis $1.0 \%$ extract emulsion. This implies that C. occidentalis $1.0 \%$ extract has more activity on the dermatophyte when compared with $C$. alata as also seen in the observed mild Inflammation of the skin (Table 6). Tissue destruction of the skin were however mild in the two groups (Fig.10). In group 6a, there was few presence of fungal hyphae which indicated that the $2 \%$ extracts were active against the dermatophyte. Moderate amount of hair follicles enmeshed within the sparse connective tissue in the dermis were seen. There were also moderate amount of sebaceous glands in the dermis.

Inflammation and tissue destruction of the skin were however mild in the group. Same observations were also seen in group $6 b$ treated with emulsion containing $2 \%$ extracts of the medicinal plants. Same observations were also seen in group 6b. There was few presence of fungal hyphae in group 6a. Moderate amount of hair follicles enmeshed within the sparse connective tissue in the dermis were seen. There were also moderate amount of sebaceous glands in the dermis.

Figs. 11 and 12 shows comparative effectiveness of the formulations on keratinization compared with the infected untreated control. Significant efficacy was demonstrated by $1 \%$. 
Table 5. Mycological efficacy of $C$. alata formulations against Trichophyton mentagrophytes

\begin{tabular}{|c|c|c|c|c|c|}
\hline Group & $\begin{array}{l}\text { Fungal } \\
\text { hyphae }\end{array}$ & Hair follicles & $\begin{array}{l}\text { Sebaceous } \\
\text { gland }\end{array}$ & Inflammation & $\begin{array}{l}\text { Continuity/Tissue } \\
\text { destruction }\end{array}$ \\
\hline 1 & ++ & + & + & +++ & ++ \\
\hline 2 & - & +++ & +++ & - & - \\
\hline 3 & ++ & + & + & ++ & ++ \\
\hline $4 a$ & ++ & + & + & ++ & ++ \\
\hline $4 b$ & ++ & + & + & ++ & ++ \\
\hline $5 a$ & ++ & + & + & ++ & ++ \\
\hline $5 b$ & ++ & + & + & ++ & ++ \\
\hline $6 a$ & + & ++ & ++ & + & + \\
\hline $6 b$ & + & ++ & ++ & + & + \\
\hline
\end{tabular}

Table 6. Mycological efficacy of C. occidentalis formulations against Trichophyton mentagrophytes

\begin{tabular}{llllll}
\hline Group & $\begin{array}{l}\text { Fungal } \\
\text { hyphae }\end{array}$ & Hair follicles & $\begin{array}{l}\text { Sebaceous } \\
\text { gland }\end{array}$ & Inflammation & $\begin{array}{l}\text { Continuity/Tissue } \\
\text { destruction }\end{array}$ \\
& +++ & - & - & ++ & ++ \\
2 & - & ++ & ++ & - & - \\
3 & ++ & + & + & ++ & ++ \\
$4 a$ & ++ & + & + & ++ & ++ \\
$4 \mathrm{~b}$ & ++ & + & + & ++ & ++ \\
$5 \mathrm{a}$ & ++ & ++ & ++ & + & ++ \\
$5 \mathrm{~b}$ & ++ & ++ & ++ & + & ++ \\
$6 \mathrm{a}$ & + & ++ & ++ & + & + \\
$6 \mathrm{~b}$ & + & ++ & ++ & + & + \\
\hline \multicolumn{7}{c}{}
\end{tabular}

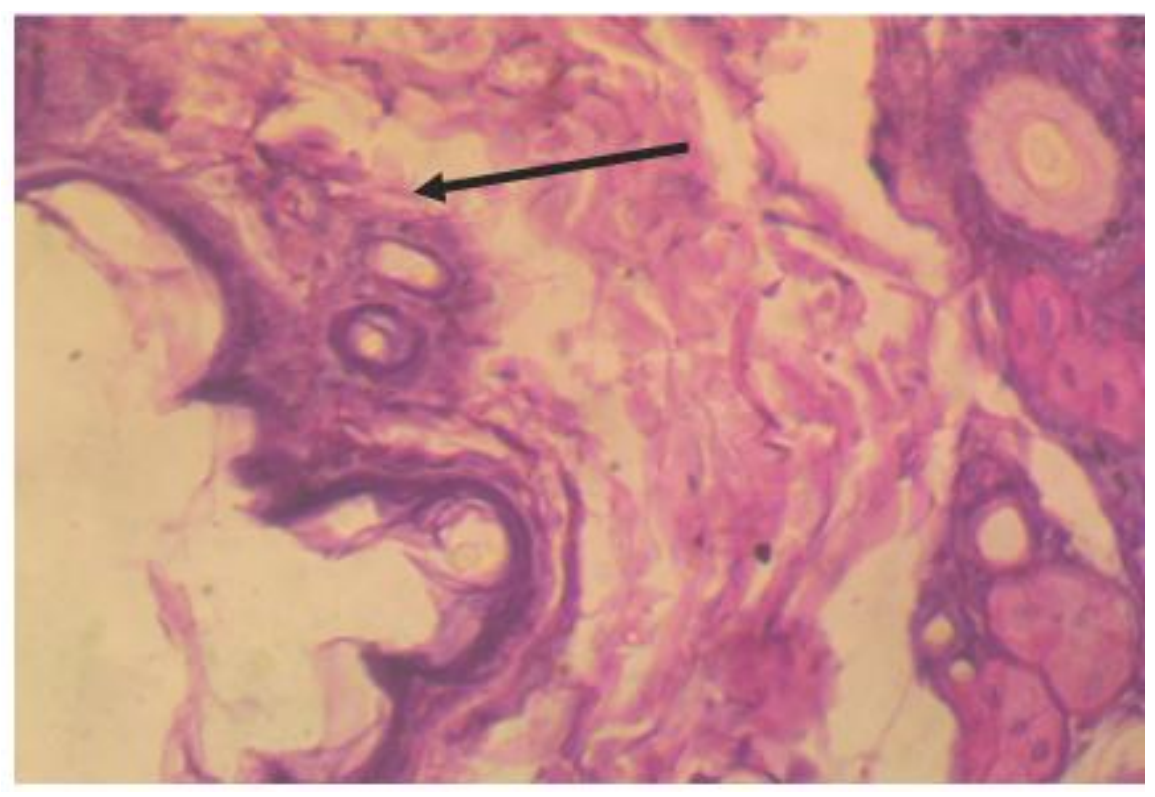

Fig. 9. There is no observable lesion. HE x400 


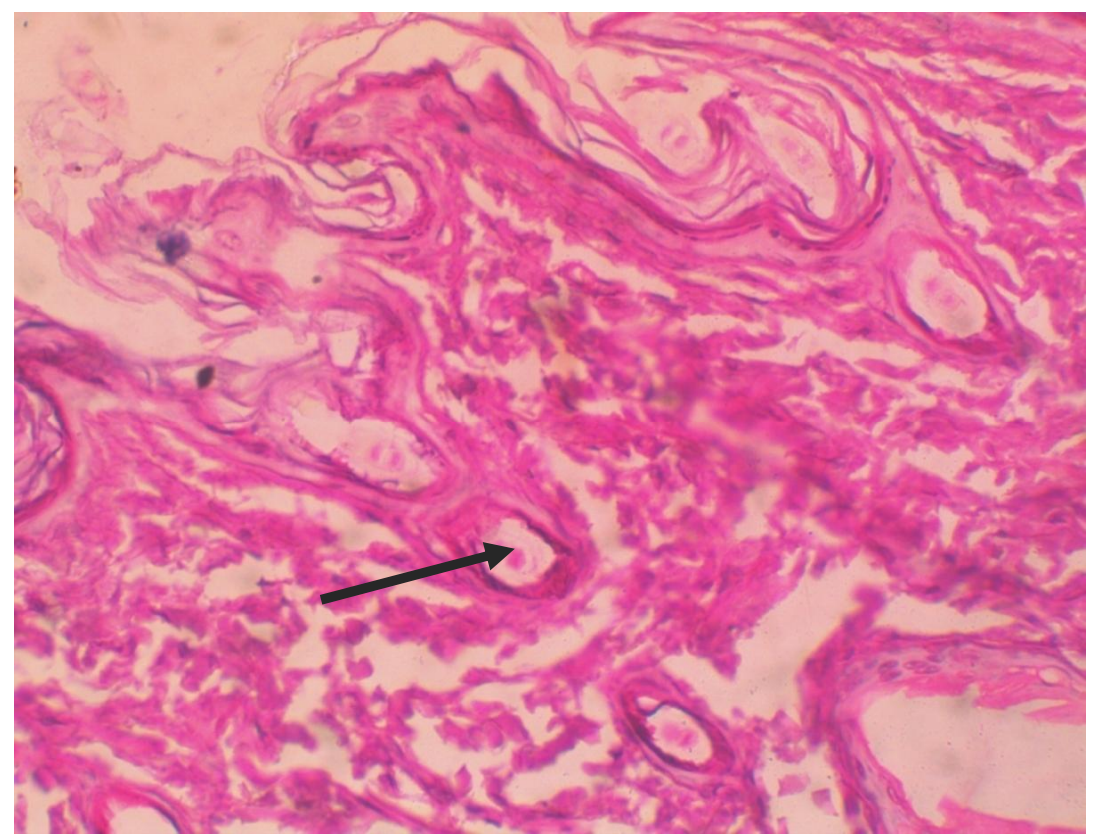

Fig. 10. There is severe thickeneing of the epidermis. HE x100

Clotrimazole cream. There was significant effect of $0.5 \%$ C. alata formulations compared to that of C. Occidentalis formulations. The values obtained for $1 \%$ C. alata extract alone $(24.34 \pm$ $0.53 \mu \mathrm{m})$ and $1 \%$ C. alata emulsion $(24.64 \pm 0.53$ $\mu \mathrm{m}$ ) indicated more efficacy by the formulations compared to what was obtained for $1 \% \mathrm{C}$. occidentalis extract alone $(22.31 \pm 0.02 \mu \mathrm{m})$ and $1 \%$ a C. occidentalis extract emulsion $(22.42 \pm$ $0.22 \mu \mathrm{m})$. Same trend was observed for $2 \%$ extracts and emulsion of the two medicinal plants. There is significant difference in keratinization between the groups as determined by one way Anova $\left(F_{6,28}=211.553, p<0.05\right)$.

\subsection{Malassezia furfur}

The skin biopsies of animals infected with the dermatophyte showed marked inflammation of the skin and foci of discontinuity of the epidermis as observed in group 1. Marked inflammation of the skin and foci of discontinuity of the epidermis were also observed (Table7). This indicated successful infection. Marked tissue destruction was observed in the group compared to the other groups which were treated with various formulations (Fig 13). There was marked presence of fungal hyphae. There were no hair follicles which indicated that the dermatophyte was feeding on the follicles (Table 8).Very few sebaceous glands were seen. In contrast, no inflammation and tissue destruction was observed in the group treated with $1 \%$ clotrimazole (group 2) which indicated that the drug was able to prevent the growth of the hyphae by the dermatophyte (Fig.14). No fungal hyphae were seen in the group. There were also numerous hair follicles in the dermis and also abundant sebaceous glands (Table 7). In The group treated with emulsion alone (group 3), inflammation and tissue destruction of the skin were moderate. There was moderate presence of fungal hyphae which indicated that the cream alone has some medicinal effect on the dermatophyte. However the group also has few sebaceous glands in the dermis.

Moderate fungal hyphae were seen in groups $4 a$ $(0.5 \%$ plants extract alone). While few hair follicles enmeshed within the sparse connective tissue in the dermis were seen in the group treated with $C$. occidentalis extract alone, Moderate amount was seen in the group treated C. alata extract alone. There are few sebaceous glands in the dermis and moderate destruction of the tissues. Same observation was made for 


\section{samples}

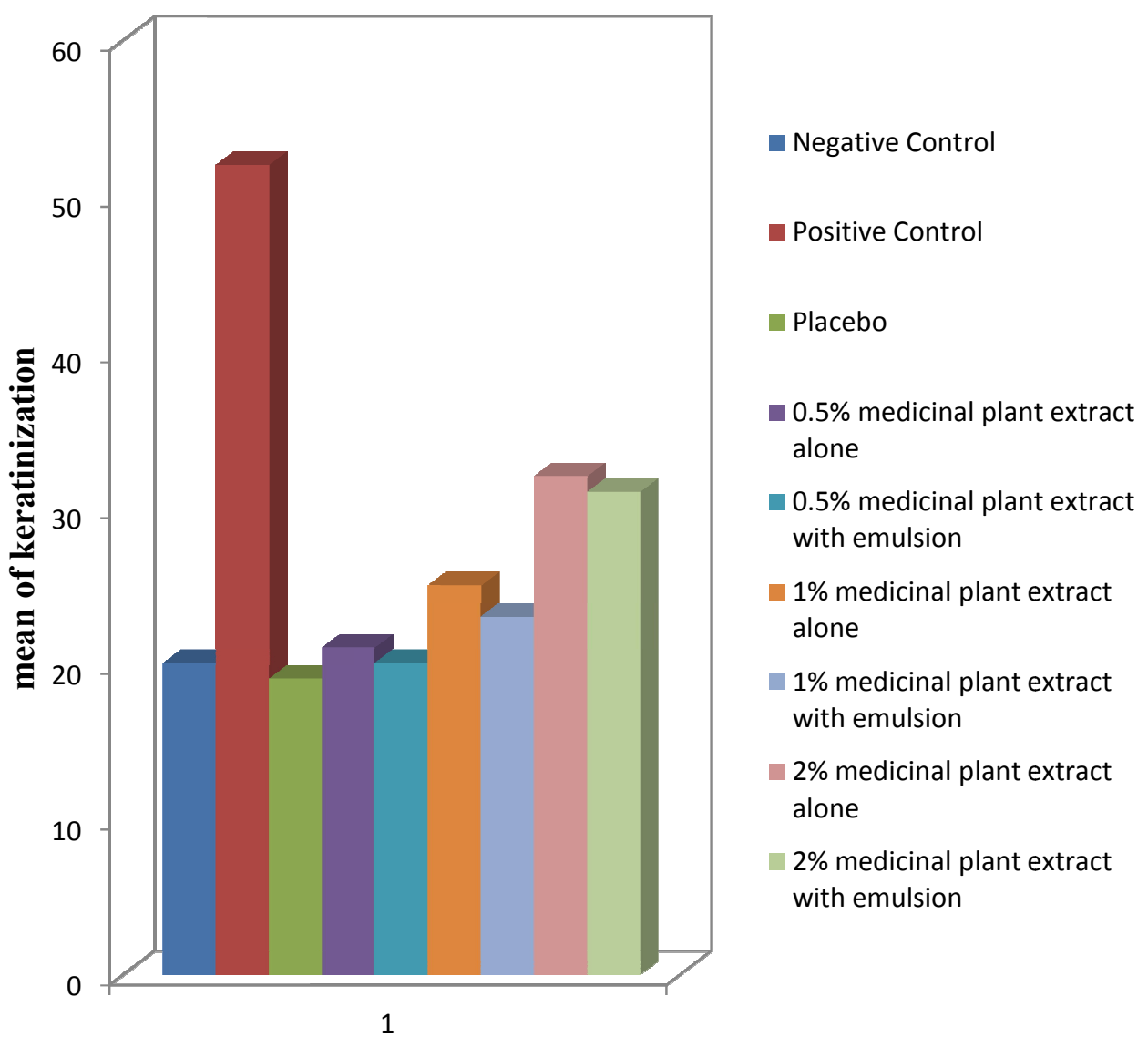

Fig. 11. Effect of Cassia alata extracts on keratinization in Trichophyton mentagrophyte infected skin

animals in group $4 \mathrm{~b}(\mathrm{C}$. alata and C. occidentalis 0.5 extract emulsion). However, in group 5a treated with $C$. alata $1 \%$ plant extract alone, few amount of fungal hyphae with moderate amount of hair follicle and sebaceous gland were observed. The inflammation and tissue destruction of the skin were mild (Table 7). Same observation were recorded for $5 b$ (C. alata $1 \%$ plant extract in emulsion). But the other group of 5a (C. occidentalis $1 \%$ extract alone) showed that there more fungal hyphae with few hair follicles and sebaceous gland. It was also observed that the inflammation and tissue destruction observed was more compared to what was observed for the other group trated with $C$. alata $1 \%$ extract alone. Same observation was recorded for $5 b$ ( Table 8.)
No fungal hyphae were seen in group 6a ( $C$. alata $2 \%$ plant extract alone) which indicated that the extract was able to prevent hyphae growth by the dermatophyte. There were moderate hair follicles in the dermis and also moderate amount of sebaceous glands. Mild inflammation of the skin and mild tissue destruction was also recorded (Table 8 and Fig. 13). Same observation was made for group 6b. However in the other group 6a treated with $\mathrm{C}$. occidentalis $2 \%$ extract alone, there was moderate presence of fungal hyphae and hair follicles. Moderate presence of sebaceous glands were also recorded while inflammation and tissue descruction were mild. Same observation was made for group 6b (Fig. 14). 


\section{samples}

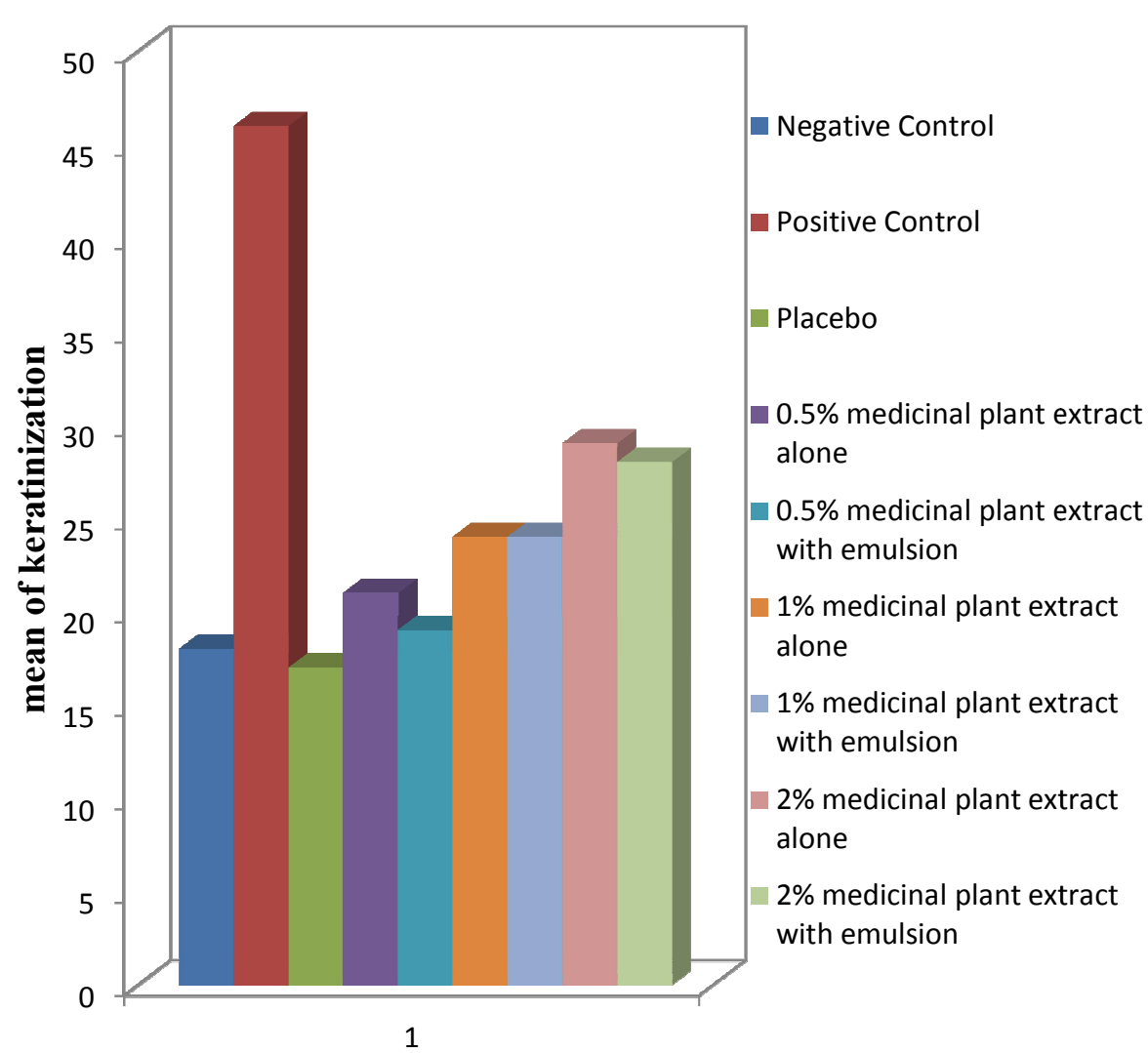

Fig.12. Effect of Cassia occidentalis extracts on keratinization in Trichophyton mentagrophytes infected skin

Fig.15 and Fig. 16 showed the comparative efficacy of the formulations on the keratin layer of the hair compared with the infected untreated control. The untreated control were heavily infected with the dermatophyte. The high vale recorded indicated effectiveness of $1 \%$ clotrimazole cream in preventing attack by the dermatophyte on the keratin layer of the hair. However, the group treated with the emulsion alone indicated there was little efficacy. Application of $0.5 \%$ C. alata and C. Occidentalis extract emulsion and $0.5 \%$ C. alata and $C$. Occidentalis extract alone on the infected skin of the animal showed some difference from the untreated group with $C$. Occidentalis extract emulsion showing more activity. This implies that they had some effect in curtailing the infection caused by the dermatophyte. The efficacy of the formulations increased as the concentration increases which can been seen in the group treated with $1 \%$ C. alata and C. occidentalis extract alone and $1 \%$ C. alata and C. occidentalis emulsion. It was observed that $2 \%$.

C. occidentalis alone and $2 \%$ C. occidentalis extract emulsion were more effective than $2 \% C$. alata extract alone and $2 \% \quad$ C. alata extract emulsion.

There is significant difference in keratinization between the groups as determined by one way Anova $\left(F_{6,28}=145.715, p<0.05\right)$. Using Tukey's post hoc test which confirms the difference. 
Table 7. Mycological efficacy of $\boldsymbol{C}$. alata ethanol formulations against Malassezia furfur

\begin{tabular}{llllll}
\hline Group & $\begin{array}{l}\text { Fungal } \\
\text { hyphae }\end{array}$ & Hair follicles & $\begin{array}{l}\text { Sebaceous } \\
\text { gland }\end{array}$ & Inflammation & $\begin{array}{l}\text { Continuity/Tissue } \\
\text { destruction }\end{array}$ \\
\hline 1 & ++ & - & + & +++ & +++ \\
2 & - & ++ & +++ & - & - \\
3 & ++ & + & + & ++ & ++ \\
$4 \mathrm{a}$ & ++ & ++ & + & ++ & ++ \\
$4 \mathrm{~b}$ & ++ & ++ & + & ++ & ++ \\
$5 \mathrm{a}$ & + & ++ & ++ & + & + \\
$5 \mathrm{~b}$ & + & ++ & ++ & + & + \\
$6 \mathrm{a}$ & - & ++ & ++ & + & + \\
$6 \mathrm{~b}$ & - & ++ & ++ & + & + \\
\hline \multicolumn{7}{r}{}
\end{tabular}

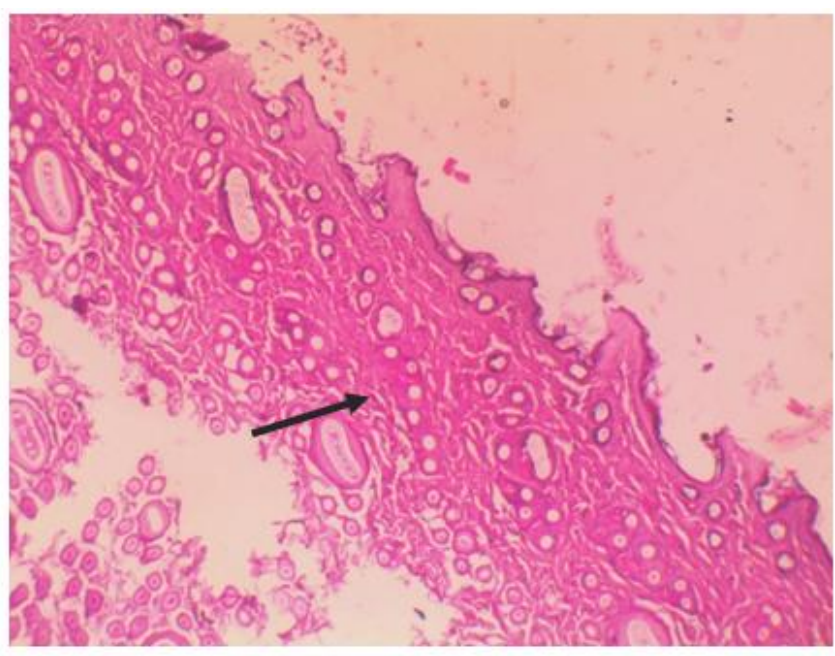

Fig. 13. There is increased deposit of connective tissue (HE x400)

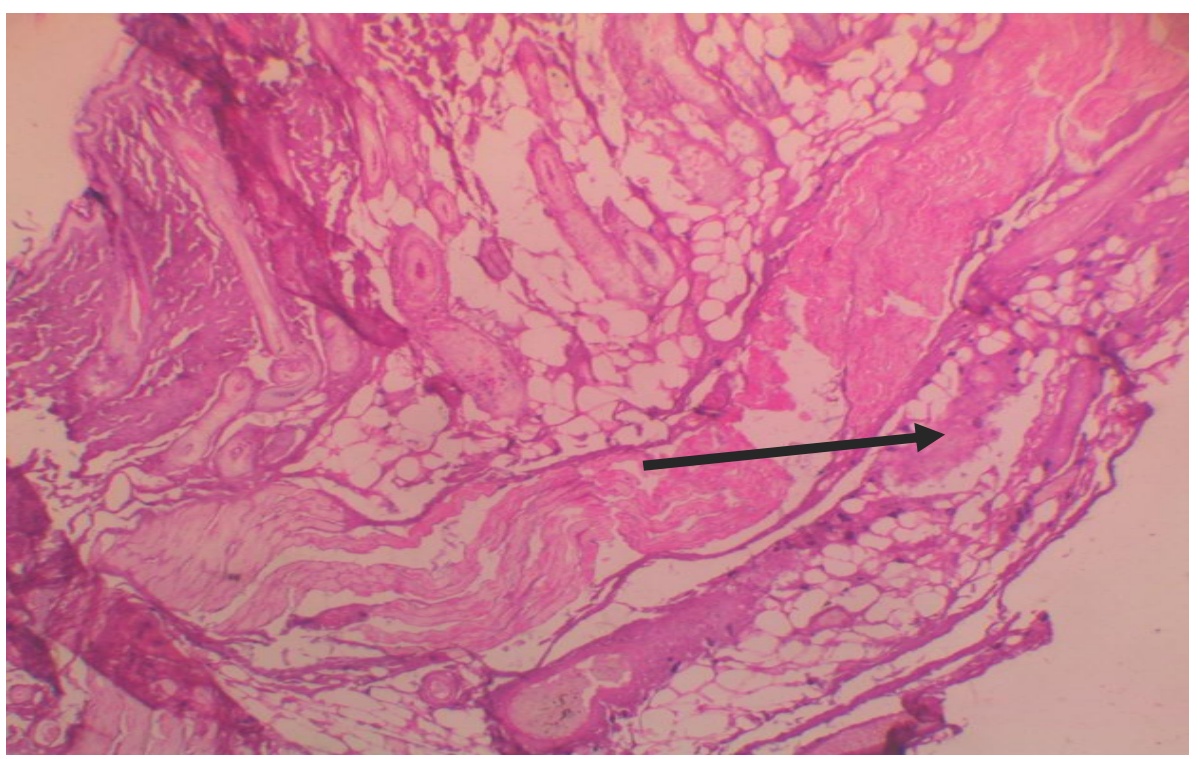

Fig. 14. There is absence of sebaceous gland. HE x100 


\section{samples}

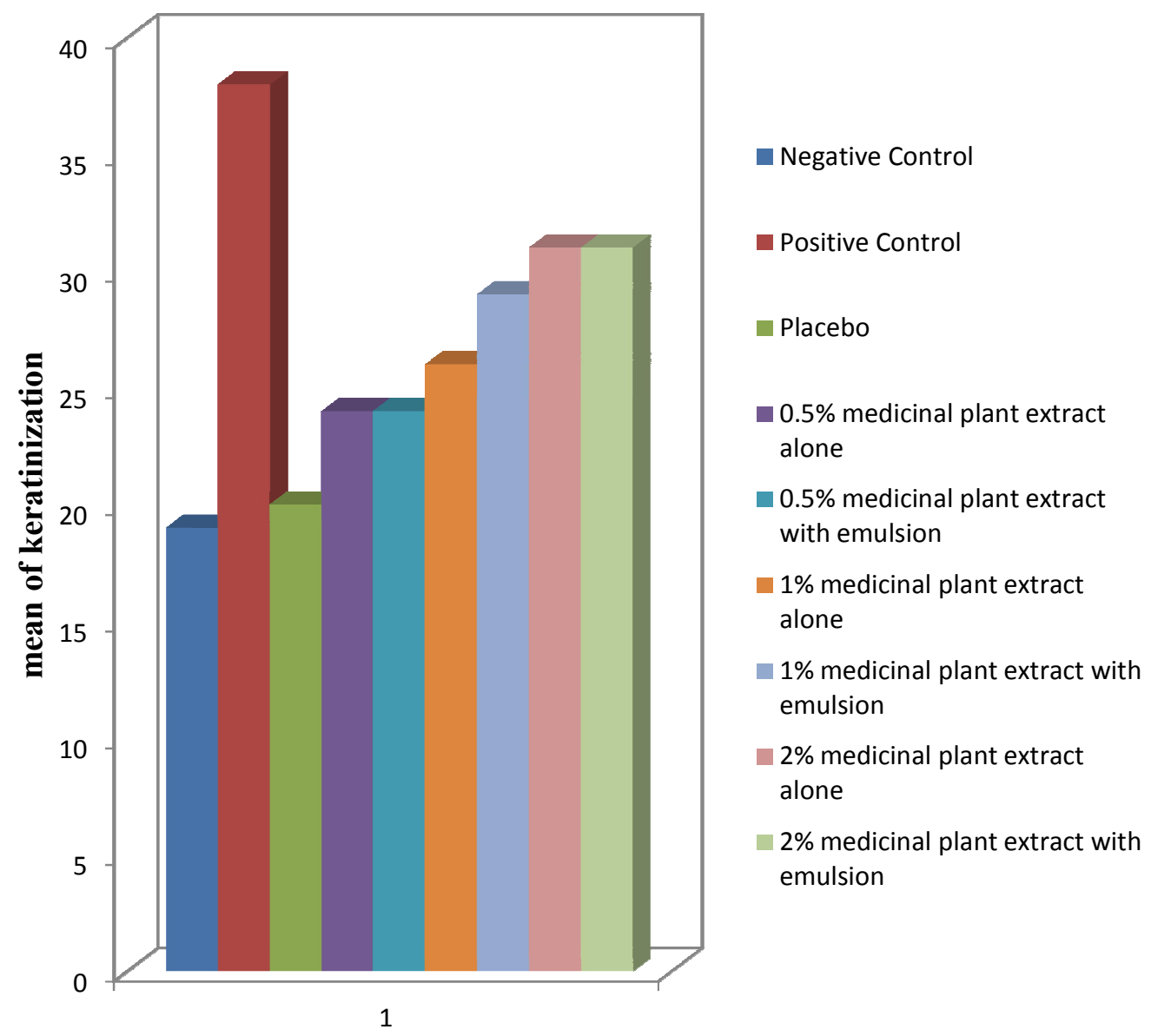

Fig. 15. Effect of Cassia alata extracts on keratinization in Malassezia furfur infected skin

Table 8. Mycological efficacy of C. occidentalis formulations against Malassezia furfur

\begin{tabular}{llllll}
\hline Group & $\begin{array}{l}\text { Fungal } \\
\text { hyphae }\end{array}$ & Hair follicles & $\begin{array}{l}\text { Sebaceous } \\
\text { gland }\end{array}$ & Inflammation & $\begin{array}{l}\text { Continuity/Tissue } \\
\text { destruction }\end{array}$ \\
\hline 1 & ++ & + & + & +++ & +++ \\
2 & - & ++ & ++ & + & - \\
3 & ++ & + & + & ++ & ++ \\
$4 \mathrm{a}$ & ++ & + & + & ++ & ++ \\
$4 \mathrm{~b}$ & ++ & + & + & ++ & ++ \\
$5 \mathrm{a}$ & ++ & + & + & ++ & ++ \\
$5 \mathrm{~b}$ & ++ & + & + & ++ & ++ \\
$6 \mathrm{a}$ & ++ & ++ & ++ & + & + \\
$6 \mathrm{~b}$ & ++ & ++ & ++ & + & + \\
\hline \multicolumn{7}{r}{}
\end{tabular}




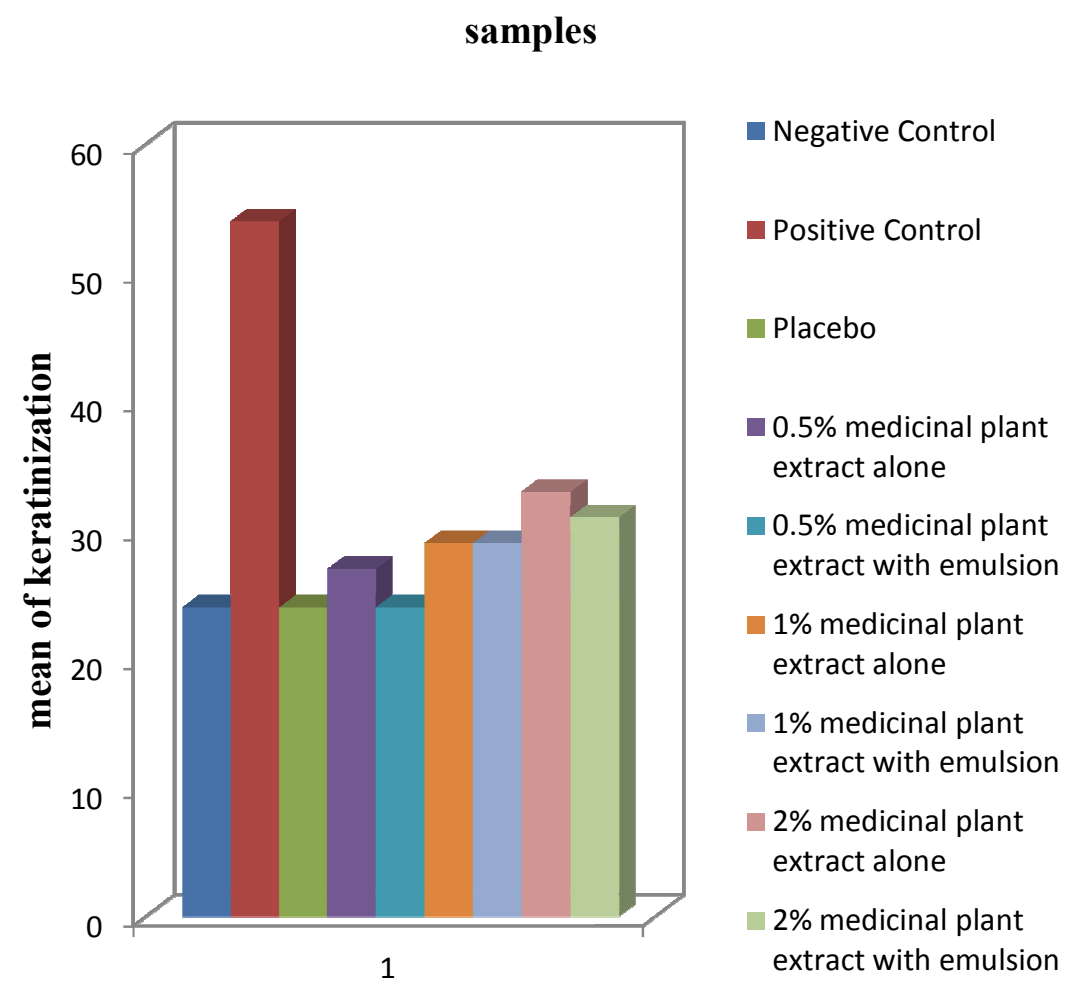

Fig. 16. Effect of Cassia occidentalis extracts on keratinization in Malassezia furfur infected skin

\section{CONCLUSION}

Medicinal effect of $C$. alata and $C$. Occidentalis extracts have been reported by various scientists. There have been reports supporting the idea that incorporating the extracts into a well formulated cream could be effective in the management of dermatophytosis [13]. The results of the present study are in accordance with the previous records regarding the invitro antifungal tests carried out on the extracts. It is possible that the efficacy of the ethanol extracts of the medicinal plants may be due to the presence of phytochemicals in the extracts such as alkaloids, saponins and phenols [10]. Comparatively, C. alata ethanol extract was more active against Microsporium aoudini, Epidermophyton floccosum and Trichophyton mentagrophytes while C. Occidentalis was more active against Malassezia furfur.

\section{ACKNOWLEDGEMENT}

Our sincere appreciation goes to Dr. A Raheem of Spectralab Medical and Diagnostic Services,
Sagamu, Ogun State for providing the clinical strains of the dermatophytes used.

\section{DISCLAIMER}

The products used for this research are commonly and predominantly use products in our area of research and country. There is absolutely no conflict of interest between the authors and producers of the products because we do not intend to use these products as an avenue for any litigation but for the advancement of knowledge. Also, the research was not funded by the producing company rather it was funded by personal efforts of the authors.

\section{ETHICAL APPROVAL}

Animal Ethic committee approval has been taken to carry out this study.

\section{COMPETING INTERESTS}

Authors have declared that no competing interests exist. 


\section{REFERENCES}

1. Ekramy A. EL-Khateeb; Adel A,Imam; Mohammed A Sallam. Pattern of Skin diseases in Cario, Egypt. 2011;50(7):884853.

DOI:10.1111/j.1365-4632.2010.04840.x

2. Gibbs S. Skin diseases and socioeconomic conditions in rural Tanzania. Int,J Dermatol 1996;35:633-639.

3. Olasode OA, Akpan NA, Bisong EB. Severe Tinea Corporis resulting from the use of tropical steriods as skin lifghtening Report of three cases. Sudanese J Derma tol 2007;5(2)67-71.

4. Fawehinmi AB, Oyedeji FO. Evaluation of Formulated Anti-dermatophyte Creams from Ethanol Extract of Mitracarpus villos us Leaves. International Journal of Biochemistry Research \& Review. 2020; 29(9):1-12.

5. Kudatarkar NM. Pharmacological Scree ning of Cassia alata Leaves on Colorectal Cancer. Colorec Cancer. 2018; 4;1:02.

DOI: 10.21767/2471-9943.100049

6. Ayo, Rachael. Phytochemical constituents and bioactivities of the extracts of Cassia nigricans Vahl: A review. Journal of Medici nal Plants Research. 2010;4:13391348.

7. Wahab, Aneela, Fayyaz, Nida. Luteolin and Kaempferol from Cassia Alata.

Fuuast J. Biology. 2014;4(1):1-5.
8. Ramstad E. Modern Pharmacogn osy. McGraw-Hill. 1959:226.

9. Alalor CA, Igwilo $\mathrm{Cl}$, Jeroh $\mathrm{E}$, Assessment of Antifungal Potential of Aqueous and Met hanol Extracts of Cassia alata. Asian Jo $r$ nal of Biological Sciences. 2012;5:120125.

DOI:10.3923/ajbs.2012.120.125

10. Thomass $O 0$ Re-examination of the antimicrobial activities of Xylopia aethiopi ca, carica papaysa, Ocimum gratissimunm and Jathropha curcas. Fitotropia. 1989;6 : 147-155.

11. Sathya A, Ambikapathy V, Panneer SA. Pelagia Research Library Studies on the phytochemistry, antimicrobial activity and antioxidant properties of Cassia occident alis L. Asian Journal of Plant Sci ence and Research. 2012;4:530-533.

12. Irobi ON, Daramola SO, Tasie SB, Oyekke SB, Tsado ML. Bacterial properties of crude extracts of Mitracarpus villos I (SW) D. C (Synonym Mitracarpus scaber Zucc.) Rubiaceae. Nigerian Journal of Microbi ology. 2006;1993;9:9-12.

13. Fawehinmi AB, Oyedeji FO Comparative Studies on the Actiivity of Extracts and Stability of Antidermatophytic Creams For mulated from Cassia occidentalis Leaves Linn. World Journal of Pharmaceutical and Medical Research Wjpmr.2021;7(1):82-88. DOI:https://doi.org/10.17605/OSF.IO/TW3 AV

(c) 2021 Oyedeji et al.; This is an Open Access article distributed under the terms of the Creative Commons Attribution License (http://creativecommons.org/licenses/by/4.0), which permits unrestricted use, distribution, and reproduction in any medium, provided the original work is properly cited.

Peer-review history:

The peer review history for this paper can be accessed here: http://www.sdiarticle4.com/review-history/66149 